\title{
KELEKATAN ORANGTUA UNTUK PEMBENTUKAN KARAKTER ANAK
}

\author{
Suci Lia Sari ${ }^{1}$, Rika Devianti ${ }^{2}$, Nur'aini Safitri ${ }^{3}$ \\ ${ }^{1}$ Sekolab Tinggi Agama Islam Auliurrasyidin Tembilahan. \\ ${ }^{2}$ Sekolab Tinggi Agama Islam Auliurrasyidin Tembilahan. \\ ${ }^{3}$ Universitas Jabal Ghafur Sigli Aceh. \\ E-mail: suciliasari@gmail.com \\ anggunmamae@gmail.com \\ aini.ahmadhazi@gmail.com
}

\begin{abstract}
ABSTRAK: Education plays an important role in developing the potential of learners, if potential learners can develop optimally then learners will have spiritual spiritual power. Learners are able to control themselves in accordance with piety to God, smart in accordance with the potential they have, have the skills that must be in accordance with the provisions of values and norms that apply, and have good behavior. At the present time there are often problems in educational institutions, especially learners many who commit violence and crimes, things like this are contrary to the educational goals that form the intelligent character of the nation's successor. The purpose of this study to see the effect of parental attachment to the formation of children's character. This research is a research library or Research library, research conducted through data collection or scientific papers. Primary data sources are the results of research or scientific papers along with books related to parental attachment and character formation of children. The result of this study is the attachment is the bond of affection and parental attitudes in parenting, parents are able to respond, and meet the needs of children, this relationship will form an emotional bond between the child with the parents and the child's closeness with the parents, from the relationship created a sense of security. This relationship will last for long periods of time even old age and will form patterns of attachment in children. Parents' attachment to their children is able to minimize criminal acts, violence, and negative behaviors that nowadays occur in society and school, not separated from parenting.
\end{abstract}

Kata Kunci: Parental Stickiness, Character Formation

\section{PENDAHULUAN}

Akhir-akhir ini perilaku anak menjadi salah satu hal yang sangat mengkhawatirkan dan meresahkan masyarakat, seperti perilaku anak jauh dari ajaran agama, tidak menghormati orangtua, berpakaian tidak sopan, berkata kotor, merokok, dan yang paling meresahkan kini anakanak sudah terlibat dalam tindakan kriminal. Permasalahan ini menjadi salah satu wacana hangat yang sering dikabarkan melalui televisi, seperti sering berita tentang tindakan kriminal yang dilakukan para pelajar, kekerasan terhadap teman, tawuran, pemerkosaan, bahkan pembunuhan. Jika dianalisa permasalahan tersebut mengambarkan bahwa kehidupan anak-anak negeri mulai mencemaskan, tidak heran jika banyak yang mempertanyakan nasih generasi muda pada masa 
yang akan datang. Hal ini tentunya sangat berhubungan erat dengan nasib bangsa, karena nasib bangsa ditentukan generasi bangsanya.

Menaggapi hal tersebut, maka perilaku-perilaku negatif anak yang sering muncul perlu mendapakan perhatian khusus. Oleh karena itu, sebagai bentuk perhatian tersebut, maka terlebih dahulu memahami kondisi anak itu sendiri dan seperti hubungann dengan lingkungan sekitarnya, orangtua dan keluarga sebagai unit terkecil terkecil dalam masyarakat yang memiliki tanggung jawab dalam membantu pertubuhan dan perkembangan anak secara optimal. Orangtua merupakan orang yang pertama dikenal oleh anak, orang yang pertama dalam memberikan peamahaman hidup kepada anak, sehingga orangtua sangat berperan penting dalam pembentukan karakter anak. Akan tetapi ironisnya keluarga justru menjadi sumber ancaman dan ketidaktentraman bagi anak, karena salah perlakuan yang diberikan orang tua terhadap anak.

Pada dasarnya hubungan anak dengan orang tua merupakan sumber emosional dan kognitif bagi anak. Hubungan tersebut memberi kesempatan bagi anak untuk mengeksplorasi lingkungan maupun kehidupan social, bahkan hubungan anak pada masa-masa awal dapat menjadi model dalam hubungan-hubungan selanjutnya. Hubungan awal ini dimulai sejak anak terlahir ke dunia, bahkan sebetulnya sudah dimulai sejak janin berada dalam kandungan (Sutcliffe, 2002: 15). Senada dengan hal tersebut Ainsworth dalam Santrock (2002:24) mengatakan bahwa kelekatan yang aman (secure attachment) dalam tahun pertama memberi landasan yang penting bagi perkembangan psikologis di kemudian hari.

Keluarga berperan penting dalam pembentukan perilaku remaja, perilaku negatif pada remaja dipengaruhi oleh orangtua, orangtua memainkan peranan penting dalam perkembangan remaja. Macam-macam sikap orangtua dalam mengasuh, dilihat dari cara orangtua merespon dan memenuhi kebutuhan akan membentuk suatu ikatan emosional antara remaja dengan orangtua sebagai figur pengasuh. Menurut Bowlby (dalam Upton, 2012:82) ikatan emosi yang terbentuk antara remaja dan orangtua sebagai figur pengasuh disebut sebagai kelekatan atau attachment.

Bowbly (dalamSantrock, 2002:45) mengemukakan kelekatan adalah suatu relasi antar figur sosial tertentu dengan suatu fenomena tertentu yang dianggap mencerminkan karakteristik relasi yang unik, kelekatan yang terbentuk selama bayi memiliki pengaruh yang penting pada tahap perkembangan. Selanjutnya Bowlby (dalamArmsden dan Greenberg, 1987:429) mengemukakan kelekatan dapat terjadi pada setiap tingkatan usia, seperti pada tahap perkembangan remaja. Para ahli perkembangan mengungkapkan peran baru dari kelekatan orangtua pada remaja berperan penting dalam pembentukan tingkah laku (Santrock, 2002:41).

Kelekatan orangtua merupakan fungsi adaptif yang menyediakan landasan bagi remaja untuk berinteraksi dengan lingkungan yang lebih luas. Menurut Santrock(2002:41) kelekatan yang kokoh dapat melindungi remaja dari kecemasan dan perasaan depresi atau tekanan emosional yang berkaitan dengan masa transisi antara anak-anak ke dewasa. Kelekatan dapat membuat remaja menganggap bahwa mereka memiliki keluarga yang hangat dapat menceritakan setiap keluhan yang mereka alami.

Menaggapi hal tersebut, maka iklim keluarga negatif yang penuh dengan perselisihan perkawinan dan diwarnai dengan konflik yang lebih umum dapat menyebarkan atmosfir rumah yang membuat suasana antaranggota keluarga tidak nyaman, sehingga dapat menyebabkan anak merasakan stress, ketidakamanan dan ketidaknyamanan (Rika, 2008:30). Anak dalam lingkungan seperti itu berada dalam resiko yang tinggi mengalami perkembangan perilaku yang bermasalah, seperti agresif, berperilaku kasar, dan depresi. Hal ini dikuatkan dalam penelitian yang dilakukan oleh Chang, Lansford,Scwartz, Farver (dalam Rika, 2008:33 ) yang mengatakan bahwa adanya korelasi positif antara pengasuhan yang negatif dengan munculnya tingkah laku bermasalah pada anak. Melihat permasalahan tersebut, penulisan makalah mencoba medeskripsikan dinamika faktor kelekatan (attachment) pada anak dengan pembentukan karakter di perkembangan anak selanjutnya. 
Pada penelitian ini akan mengungkap konsep kelekatan serta pengaruh kelekatan orangtua dengan pembentuk karakter anak.

\section{KAJIAN LITERATUR}

\section{Pengertian Kelekatan}

Istilah Kelekatan (attachment) untuk pertama kalinya dikemukakan oleh seorang psikolog dari Inggris pada tahun 1958 bernama John Bowlby. John Bowlby (1907 - 1990), psikiater Inggris, menjelaskan bahwa "maternal deprivation" atau kekurangan kasih sayang ibu sering menyebabkan kecemasan (anxiety), kemarahan (anger), penyimpangan perilaku (delinquency), dan depresi. Kemudian formulasi yang lebih lengkap dikemukakan oleh Mary Ainsworth pada tahun 1969 (McCartney dan Dearing, 2002: 85).

Senada dengan hal tersebut, Papalia (2009:90) menjabarkan pengertian kelekatan sebagai hubungan timbal balik yang aktif dan bersifat afektif antara dua orang individu yang dibedakan dari orang lain dan interaksi yang terjalin antara dua individu merupakan usaha untuk menjaga kedekatan.

Ainsworth (dalam Upton, 2012:87) menjelaskan kelekatan adalah ikatan efeksional antara satu individu dengan individu lain dan berlangsung dalam jangka waktu yang lama. Bowbly (dalam Santrock, 2002:40) sangat yakin bahwa kelekatan yang terbentuk selama bayi memiliki pengaruh yang penting pada tahap perkembangan selanjutnya. Lebih lanjut Bowlby (dalam Armsden, 1987:429) menyatakan kelekatan dapat terjadi pada setiap tingkatan usia, seperti pada tahap perkembangan remaja. Para ahli perkembangan mengungkapkan peran baru dari kelekatan orangtua pada remaja berperan penting pada masa remaja. Hal senada juga dikemukakan oleh Colin (1996:300) bahwa "kelekatan orangtua pada remaja penting dalam kehidupan remaja".

Merujuk pada pendapat di atas, maka kelekatan orangtua merupakan fungsi adaptif yang menyediakan landasan bagi anak untuk berinteraksi dengan lingkungan yang lebih luas. Menanggapi hal tersebut, Santrock(2002:41) menyatakan bahwa kelekatan yang kokoh dapat melindungi anak dari kecemasan dan perasaan depresi atau tekanan emosional yang berkaitan dengan masa transisi antara anak-anak ke dewasa. Kelekatan dapat membuat anak menganggap bahwa mereka memiliki keluarga yang hangat dapat menceritakan setiap keluhan yang mereka alami.

Berdasarkan beberapa pendapat di atas, maka kelekatan adalah hubungan timbal balik antara anak dan orangtua, yang merupakan ikatan kasih sayang dan sikap orangtua dalam mengasuh anak, orangtua mampu merespon, dan memenuhi kebutuhan anak, hubungan ini akan membentuk suatu ikatan emosional antara anak dengan orangtua dan terjalin kedekatan anak dengan orangtua, dari hubungan tersebut tercipta rasa aman. Hubungan ini akan berlangsung dalam jangka waktu yang lama bahkan usia lanjut dan akan terbentuk pola-pola kelekatan pada anak.

\section{Urgensi Kelekatan}

Banyak penelitian yang mempelajari arti penting kelekatan (attachment) dalam perkembangan individu. Seperti yang diungkapkan Belsky (1988:67) bahwa para peneliti mempelajari pengembangan hubungan kelekatan dari waktu ke waktu dan untuk menghubungkan pola kelekatan dengan perilaku berikutnya. Kelekatan telah dikaitkan dengan perilaku eksplorasi dan dampaknya terhadap pembelajaran (Ainsworth dalam Santrock 2002:26). Suatu korelasi telah ditunjukkan antara pola kelekatan dan masalah perilaku dan secara rinci terdapat implikasi dari 
kelekatan untuk perilaku di sekolah (Santrock 2002:25).Banyak penelitian yang menunjukkan bahwa kelekatan memainkan peran penting dalam perkembangan.

\section{Pola Kelekatan}

Bowlby dan Ainsworth (dalam Santrock, 2007:25) menyebutkan attachment style terbagi kedalam kelompok besar yaitu secure attachment dan insecure attachment, individu yang mendapatkan secure attachment adalah percaya diri, optimis, serta mampu membina hubungan dekat dengan orang lain sedangkan individu yang mendapatkan insecure attachment adalah menarik diri, tidak nyaman dalam sebuah kedekatan, memiliki emosi yang berlebihan, dan sebisa mungkin mengurangi ketergantungan terhadap orang lain.

Bartholomew dalam (Baron dan Byrne, 2003:10) mengemukakan empat gaya attachment sebagai berikut:

\section{Gaya Kelekatan Aman (Secure Attachment Style)}

Individu dengan pola ini digambarkan sebagai individu yang mempunyai harga diri, kepercayaan interpersonal yang tinggi mempunyai pandangan yang positif dan mampu membuat hubungan interpersonal berdasarkan saling percaya. Anak yang memiliki hubungan dekat dengan orangtua menunjukkan tidak terlibat dalam aktivitas kenakalan.

\section{Gaya Kelekatan Takut Menghindar (Fearfull-Avoidant Attachment Style)}

Individu dengan pola ini mempunyai pendangan negatif terhadap dirinya dan orang lain, menderita perasaan dalam ketidakcukupan, kecemasan dan akan menghindari hubungan dekat dengan orang lain. Anak yang memiliki kelekatan ini akan berhubungan dengan kenakalan.

\section{Gaya Kelekatan Terpreukupasi (Pre-Occupied Attachment Style)}

Individu dengan pola ini mempunyai pandangan yang negatif terhadap dirinya sendiri, tetapi masih mengharap orang lain akan menerima dan mencintai dirinya, sehingga individu dengan tipe ini berusaha membuat hubungan dengan orang lain tetapi mereka takut ditolak. Anak yang memiliki pandangan positif dan negatif terhadap dirinya sendiri tidak akan mempunyai kemampuan berkompetensi sosial.

\section{Gaya Kelekatan Menolak (Dismissing Attachment Style)}

Individu dengan pola ini mempunyai karakter positif dalam memandang diri sendiri, merasa berharga, mandiri dan merasa patut untuk mendapat atau membuat hubungan dekat dengan orang lain, tetapi mereka terkadang mereka menolak hubungan yang tulus karena mereka mengharapkan orang lain yang lebih buruk dari mereka, sehingga pola ini digolongkan dalam sisi negatif. Anak dengan gaya kelekatan ini kekurangan komunikasi dan kepercayaan ditambah dengan perasaan terabaikan, biasanya berhubungan dengan masalah perilaku seperti agresif dan kenakalan-kenakalan lainnya.

Merujuk pada pendapat di atas dapat disimpulkan bahwa kelekatan orangtua dengan anak dari bayi hingga anak akan membentuk empat gaya kelekatan diataranya gaya kelekatan aman, kelekatan takut menghindar, kelekatan terpreukupasi, dan kelekatan menolak. Gaya kelekatan yang terbentuk ini akan berhubungan dengan perilaku pada anak.

\section{Aspek-aspek dari Kelekatan}

Arsmden dan Greenberg (1987:433) menjelaskan terdapat tiga aspek kelekatan diantaranya sebagai berikut. 


\section{Kepercayaan}

Orangtua memberikan kepercayaan, memahami kebutuhan, menghargai, dan menghormati pilihan maupun keputusan, melibatkan dalam menyelesikan konflik, maupun masalah yang terjadi pada remaja. Orangtua tetap mengontrol apa yang dilakukan remaja baik di sekolah maupun pergaulan remaja secara berlebihan.

\section{Komunikasi}

Orangtua membimbing remaja agar mau terbuka, membicarakan masalah yang dihadapi baik itu tentang diri sendiri maupun masalah dengan oranglain. Orangtua mampu merespon dengan baik keadaan emosional yang sedang dialami remaja, adanya kepedulian dan kekhawatiran, kemampuan memberikan dukungan dan membantu menyelesaikan masalah yang dihadapi remaja. Komunikasi yang baik antara remaja dan orangtua dapat membuat suatu individu menjadi terbuka dalam menceritakan setiap permasalahan yang dihadapinya.

\section{Pengasingan}

Pengasingan terjadi jika orangtua kurang responsif pada remaja serta tidak memberikan kepercayaan terhadap apa yang dilakukan oleh remaja.

Dari pendapat di atas dapat disimpulkan bahwa terdapat tiga aspek kelekatan yaitu kepercayaan yang diberikan orangtua terhadap apa yang dilakukan oleh remaja, menjalin komunikasi dengan baik agar mau terbuka tentang masalah yang dihadapi remaja, tidak mengasingkan remaja dari permasalahan keluarga. Banyak faktor yang mempengaruhi kelekatan orangtua dengan remaja.

\section{Faktor yang Mempengaruhi Pola Kelekatan} berikut.

Colin (1996:96) menjelaskan pola-pola kelekatan dipengaruhi oleh beberapa hal sebagai

\section{Tokoh pengasuh}

Kepribadian dari pengasuh utama dapat menentukan atau mempengaruhi pola kelekatan pada anak. Pengasuh yang menderita penyakit mental atau gangguan kepribadian mungkin mengasuh dan merespon bayi dengan cara yang menyimpang. Kemudian bayi akan mengembangkan penjagaan, mengubah, atau penyimpangan pola dari perilaku kelekatan.

\section{Faktor-faktor demografis}

Jenis kelamin bayi, urutan atau golongan sosial mempengaruhi pola kelekatan. Status sosioekonomi yang sangat rendah dapat membantu untuk meramalkan pola kelekatan terhadap ibu. Pada kasus sebuah keluarga yang sangat miskin, anxiousattachment kepada ibu lebih banyak dalam keadaan yang biasa dari pada mereka yang berada di tingkat ekonomi yang lebih baik. Keluarga dalam kemiskinan sering mengalami beragam masalah.

\section{Pengguna obat-obatan dan alkohol}

Ibu yang menggunakan alkohol atau obat-obatan saat masa kehamilan akan menyebabkan efek jangka panjang atau bahkan efek yang tidak dapat diubah pada bayi. Orang dewasa yang kecanduan obat-obatan mungkin berpengaruh banyak efek yang tidak diinginkan pada anak.

\section{Tempramen bayi}

Sifat tempramen pada bayi termasuk tingkatan aktivitas, rentang perhatian kecenderungan dalam keadaan sulit, kemarahan, takut, reaksi, emosional, menenangkan, dan ketekunan. 


\section{Kelabiran prematur dan penyakit dini}

Bayi yang prematur cenderung menunjukkan koordinasi motorik yang lemah, lebih sedikit menangis, lebih mudah marah, dan sulit merasakan kenyamanan.

\section{Dukungan sosial}

Dukungan sosial dari ibu memberikan kontribusi yang penting untuk kualitas kelekatan anak pada ibu.

Dari pendapat di atas dapat disimpulkan bahwa faktor kelekatan dipengaruhi oleh tokoh pengasuh, status ekonomi, penggunaan obat-obatan dari pengasuh, tempramen bayi, kelahiran prematur, dan dukungan sosial dari pengasuh. Orangtua sebagai pengasuh utama menentukan atau mempengaruhi pola kelekatan, sehingga bermanfaat untuk perkembangan remaja.

\section{Manfaat Kelekatan}

Santrock (2003:40) menyebutkan beberapa manfaat kelekatan adalah bisa memfasilitasi kecakapan dan kesejahteraan sosial seperti yang dicerminkan dalam beberapa ciri seperti harga diri, penyesuaian emosi, dan kesehatan fisik, membantu menunjukkan kesejahteraan emosi yang lebih baik, membantu untuk memiliki harga diri yang lebih tinggi, sebagai fungsi adaptif untuk menyediakan dasar rasa aman terhadap anak agar dapat mengeksplorasi dan menguasai lingkungan baru serta dunia sosial yang semakin luas dalam kondisi psikologi yang sehat, membantu anak dari kecemasan dan kemungkinan perasaan tertekan atau ketegangan emosi yang berkaitan dengan transisi dari masa kanak-kanak manuju ke masa dewasa, membantu keberhasilan anak dalam hubungan intim dan harga diri pada masa awal, membantu anak untuk menghasilkan hubungan positif dan dekat di luar keluarga dengan teman sebaya.

Dari pendapat di atas dapat disimpulkan bahwa manfaat kelekatan orangtua dengan anak adalah memiliki harga diri lebih tinggi, dapat mengendalikan emosi, kesehatan fisik, dapat menguasai lingkungan baru, mampu menghasilkan hubungan yang positif dengan keluarga, dan teman sebaya.

\section{Upaya Membentuk kelektan yang positif}

Menurut Tia Rahmania (2014) berbagai bentuk kelekatan yang dapat diberikan kepada anak adalah pemahaman dan pengertian tentang kebutuhan para anak dan tanggapan orangtua. Misalnya, bagaimana orangtua membuat anak merasa nyaman bila ada di dekat mereka tunjukkan sikap yang hangat dan ketertarikan pada aktivitas yang dilakukan anak mereka yang telah anak sehingga terjalin percakapan yang santai dan nyaman, dukungan orangtua terhadap pengembangan otonomi atau kemandirian anak. Misalnya, orangtua memberi kesempatan anak untuk mengambil keputusan menentukan jurusan pendidikan mereka, orangtua berperan dalam memberikan dukungan secara emosional disaat anak berada dalam masalah atau tertekan. Tentunya dukungan emosional ini akan bisa dilakukan apabila orangtua dan anak sendiri sebelumnya telah merasa nyaman mengungkapkan kondisi perasaan mereka satu sama lain, oleh karena itulah para orangtua harus bisa mendukung munculnya keterbukaan perasaan di dalam keluarga, respon yang positif. Hindari untuk mengkritik saat anak mengajukan pendapatnya, walaupun ide atau gagasan mereka tidak biasa tapi coba awali dengan meminta anak untuk mengungkapkan idenya terlebih dahulu sebelum kemudian mengajak mereka untuk berpikir konsekuensi yang bisa terjadi dari ide tersebut. Hal itu jauh lebih baik dan akan membuat anak merasa mendapatkan apresiasi sehingga terjadi keterbukaan antara orangtua dan anak.

Dari penjelasan di atas dapat disimpulkan bahwa orangtua berperan penting dalam membentuk tingkah laku anak, orangtua diharapkan dapat membentuk kelekatan yang positif, 
bentuk kelekatan yang dapat diberikan kepada anak adalah pemahaman, pengertian, memberikan kesempatan dalam mengambil keputusan, memberikan dukungan emosional, dan menghargai pendapat anak.

\section{Karakter}

Kata karakter berasal dari Bahasa Yunani yang berarti "to mark" atau menandai dan memfokuskan pada bagaimana mengaplikasikan nilai kebaikan dalam bentuk tindakan atau tingkah laku (Wynne,1991). Karakter menurut Alwisol (2006:8) diartikan sebagai gambaran tingkah laku yang menonjolkan nilai benar salah, baik-buruk, baik secara eksplisit maupun implicit. Karakter berbeda dengan kepribadian, karena pengertian kepribadian dibebaskan dari nilai. Meskipun demikian, baik kepribadian (personality) maupun karekter berwujud tingkah laku yang ditunjukkan ke lingkungan sosial.

Karakter mengacu pada sikap, perilaku, motivasi dan keterampilan yang dimiliki individu. Menurut Musfiroh (2008) karakter meliputi sikap seperti keinginan untuk melakukan hal yang terbaik,kapasitas intelektual seperti berfikir kritis dan alasan moral, perilaku seperti berkata jujur dan bertanggungjawab, mempertahankan prinsip-prinsip moral dalam situasi penuh ketidakadilan, kecakapan interpersonal dan emosional yang memungkinkan seseorang berinteraksi secara efektif dalam berbagai keadaan dan komitmen untuk berkontribusi dengan komunitas dan masyarakatnya. Karakteristik adalah realisasi perkembangan positif sebagai individu berupa intelektual, social, emosional serta etika. Individu yang dikatan berkarakter baik adalah individu yang selalu berusaha melakukan hal yang terbaik (Battistich,2008)

Pengertian secara berbeda-beda diartikan oleh berbagai pihak, sebagian menyatakan kalau karakter merupakan sebuah penilaian yang subyektif terhadap moral dan mental seseorang, stimulus yang berperan penting untuk membentuk karakter individu. Coon (1983) membrikan defenisi karakter merupakan salah satu penilaian subyektif terhadap kepribadian seseorang yang berkaitan dengan atribut kepribadian yang dapat atau tidak diterima seseorang atau masyarakat luas.

Karakter individu dapat dipengaruhi oleh pertama adalah factor bawaan yang dibawa sejak lahir, karakter seseorang diwarisi dari kedua orangtua, kedua adalah lingkungan berupa polah asuh orangtua, lingkungan social yang pertama dikenal anak dari sejak lahir adalah orangtua (ibu, ayah, serta anggota keluarga lainnya), dalam keluarga anak mendapatkan pendidikan pertama salahsatunya pendidikan karakter, dituntut orangtua membentuk sejak dini karakter anak dengan pengenalan nilai-nilai, moral dan kebiasaan-kebiasan positif bagi anak. Menurut para ahli psikologi, manusia sejak lahir membawa potensi bawaa yang akan termasuk potensi karakter dan memiliki nilai nilai dasar dalam diri individu. Confisius (dalam Magawangi, 2003) menyatakan bahwa pada dasarnya manusia atau individu memiliki potensi cinta kabijakan, potensi ini perlu dikembangkan melalui pendidikan, jika tidak dikembangkan potensi akan menjadi lebih buruk seperti halnya binatang.

Lickona (1991) menyatakan bahwa konsep moral memiliki komponen kesadaran moral, pengetahuan moral, pandangan ke depan, penalaran moral, pengambilan keputusan serta pengetahuan diri. Kemudian sikap moral memiliki komponen kata hati, rasa percaya diri, empati, cinta, kebaikan, pengendalian diri serta kerendahan diri. Sedangkan perilaku moral terdiri dari komponen moral dimiliki seseorang akan membentuk karakter yang baik atau tangguh atau unggul. Berikut Gambar 1, merupakan keterkaitan antara ketiga komponen dalam rangka pembentukan karakter yang baik menurut Lickona : 


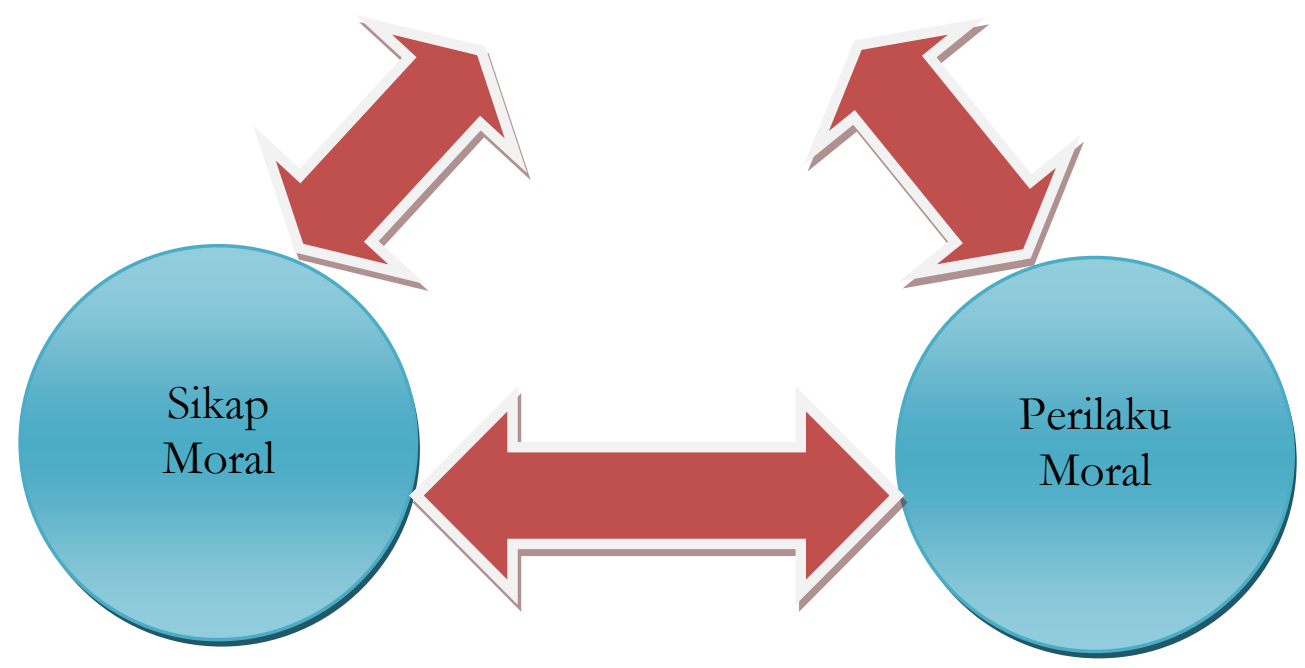

Gambar 1. Keterkaitan antara ketiga komponen moral untuk membentuk karakter

\section{Ruang Lingkup Pembentukan Karakter}

Dalam buku Kebijakan Nasional Pembangunan Karakter Bangsa 2010-2012yang dikeluarkan oleh pemerintah Republik Indonesia (2010) menjelaskan bahwa ruang lingkup pembangunan karakter bangsa meliputi (Eva Imania Eliasa: 2011)

\section{Lingkup Keluarga}

Keluarga merupakan wahana pembelajaran dan pembiasaan karakter yang dilakukan oleh orang tua dan orang dewasa lain dalam keluarga terhadap anak sebagai angota keluraga sehingga diharapkan dapat terwujud keluarga berkarakter mulia yang tercermin dalam perilaku keseharian. Proses ini dapat dilakukan melalui komunitas keluarga dan partisipasi keluarga dalam pengelolaan pendidikan dan pemberdayaan masyarakat. Keluarga merupakan lingkungan yang pertama dan utama dimana orang tua bertindak sebagai pemeran utama dan panutan bagi anak. Proses itu dapat dilakukan dalam bentuk pendidikan, pengasuhan, pembiasaan dan keteladanan. Pendidikan karakter dalam lingkup keluarga dapat juga dilakukan kepada komunitas calon orang tua dengan penyertaan pengetahuan dan keterampilan, khususnya dalam pengasuhan dan pembimbingan anak.

\section{Lingkup Satuan}

PendidikanSatuan pendidikan merupakan wahana pembinaan dan pengembangan karakter yang dilakukan dengan menggunakan (1) pendekatan terintegrasi dalam semua mata pelajaran; (2) pengembangan budaya satuan pendidikan; (3) pelaksanaan kegiatan kokurikuler dan ekstrakurikuler; serta (4) pembiasaan perilaku dalam kehidupan di lingkungan satuan pendidikan. Pembangunan karakter melalui satuan pendidikan dilakukan mulai dari pendidikan anak usia dini sampai perguruan tinggi. 


\section{Lingkup Pemerintahan.}

Pemerintaha merupakan wahana pembangunan karakter bangsa melalui keteladanan penyelenggara negara, elite pemerintah dan elite politik.

\section{Lingkup Masyarakat Sipil}

Masyarakat sipil merupakan wahana pembinaan dan pengembangan karakter melalui keteladanan tokoh dan pemimpin masyarakat serta berbagai kelompok masyarakat yang tergabung dalam organisasi social kemasyarakatan sehingga nilai-nilai karakter dapat diinternalisasi menjadi perilaku dan budaya dalam kehidupan sehari-hari.

\section{Lingkup Masyarakat Politik}

Masyarakat merupakan wahana yang melibatkan warga Negara dalam penyaluran aspirasi dalam politik.

\section{Lingkup Dunia Usaha dan Industri}

Dunia usaha dan industri merupakan wahana interaksi para pelaku sektor riil yang menopang bidang perekonomian nasional. Kemandirian perekonomian nasional sangat bergantung pada kekuatan karakter para pelaku usaha dan industry yang diantaranya dicerminkan oleh menguatnya daya saing, meningkatnya lapangan kerja dan kebanggan terhadap produk bangsa sendiri.

Lingkup Media Massa Media massa merupakan wahana sebuah fungsi dan system yang member pengaruh sangat signifikan terhadap politik, khususnya terkait dengan pembentukan nilainilai kehidupan, sikap, perilaku dan kepribadian atau jati diri bangsa (2010;6). Dari paparan diatas, dijelaskan kedudukan keluarga sebagai salah satu ruang lingkup pembangunan karakter bangsa, mempunyai peran yang penting dalam pendidikan karakter bagi putra-putrinya.

Dari paparan diatas, dijelaskan kedudukan keluarga sebagai salah satu ruang lingkup pembangunan karakter bangsa, mempunyai peran yang penting dalam pendidikan karakter bagi putra-putrinya. Posisi keluarga sebagai wahana awal pembentukan kepribadian anak yang berkarakter. Anak mendapatkan kesan pertama mengenai dunia melalui perilaku dan sikap orang tua, terutama ibu terutama di awal usianya. Jika ibu berlaku baik maka kesan anak tentang dunia dan lingkungan positif dan sikap anak juga akan menjadi positif

Seorang ibu dalam pengasuhannya mengenalkan konsep moral dengan bahasa yang mudah dipahami sang anak, menerapkan perilaku yang mencerminkan sikap menjunjung tinggi moral dalam kesederhanaan bagi karakter anak. Namun bila terjadi sesuatu, seperti ternyata ada kesalahan dari orang tua dalam mengasuh dan mendidik anaknya, perlu diperhatikan lebih seksama lagi. Pendapat ini merujuk pada uraian Megawangi (Melly Latifah, 2008) menjelaskan bahwa ada beberapa kesalahan orang tua dalam mendidik anak yang dapat mempengaruhi perkembangan kecerdasan emosi anak sehingga berakibat pada pembentukan karakternya, yaitu kurang menunjukkan ekspresi kasih sayang baik secara verbal maupun fisik, kurang meluangkan waktu yang cukup untuk anaknya, bersikap kasar secara verbal, misainya menyindir, mengecilkan anak, danberkata-kata kasar, bersikap kasar secara fisik, misalnya memukul, mencubit, dan memberikanhukuman badan lainnya, terlalu memaksa anak untuk menguasai kemampuan kognitif secara dini, tidak menanamkan "good character' kepada anak. 
Bila terjadi kegagalan keluarga sehingga menimbulkan dampak yang sangat berat seerti diatas, maka perlu kerjasama berbagai fihak yang terkait untuk mencegah permasalahan yang berkepanjangan.Kegagalan keluarga dalam melakukan pendidikan karakter pada anak-anaknya, akan mempersulit institusi-institusi lain di luar keluarga (termasuk sekolah) dalam upaya memperbaikinya. Kegagalan keluarga dalam membentuk karakter anak akan berakibat pada tumbuhnya masyarakat yang tidak berkarakter. Oleh karena itu, setiap keluarga harus memiliki kesadaran bahwa karakter bangsa sangat tergantung pada pendidikan karakter anak-anak mereka dalam keluarga.

Dampak yang ditimbulkan dari salah asuh seperti di atas, menurut Megawangi (Latifah,2008) akan menghasilkan anak-anak kelak pada masa perkembangannya mempunyai kepribadian bermasalah atau mempunyai kecerdasan emosi rendah, seperti anak menjadi acuh tak acuh, secara emosiol tidak responsive, berperilaku agresif, menjadi minder, selalu berpandangan negatif pada lingkungan sekitarnya, ketidakstabilan emosional, yaitu tidak toleran atau tidak tahan terhadap stress, mudah tersinggung, mudah marah, dan sifat yang tidak dapat dipreaiksi oleh orang lain, keseimbangan antara perkembangan emosional dan intelektual. Dampak negative lainnya dapat berupa mogok belajar, dan bahkan dapat memicu kenakalan remaja, tawuran, dan lainnya, orang tua yang tidak memberikan rasa aman dan terlalu menekan anak.

Oleh sebab itu, kesalahan keluarga akan menimbulkan Dampak negative seperti yang diutarakan diata, dalam membentuk karakter anak diperlukan kerjasama pihak-pihak yang terkait dengan permasalahan agar mencegah kemungkinan permasalahan-permasalahan keluarga dalam memberikan pendidikana karakter. Memperbaikinya. Kegagalan keluarga dalam membentuk karakter anak akan berakibat pada tumbuhnya masyarakat yang tidak berkarakter. Oleh karena itu, setiap keluarga harus memiliki kesadaran bahwa karakter bangsa sangat tergantung pada pendidikan karakter anak-anak mereka dalam keluarga.

\section{METODOLOGI}

\section{Jenis Penelitian}

Penelitian ini menggunakan library researchyaitu suatu penelitian kepustkaan yang objek utamanya buku-buku atau sumber-sumber kepustkaan (Sutrisno Had, 2000: 9). Penulis memilih antara sumber yang memilikiotoritas keilmuan dan sumber yang hanya dijadikan sebagai pelengkap dan penunjang.

Kegiatan studi termasuk kategori penelitian kualitatif dengan prosedur kegiatan dan teknik penyajian finalnya secara deskriptif, maksudnya penelitian ini bertujuan untuk memperoleh gambaran utuh dan jelas tentang kelekatan orantua dengan pembentukan karakter.

\section{Sumber Data}

Sumber primer yang peneliti gunakan adalah hasil-hasil Penelitian atau tulisan-tulisan karya ilmiah beserta buku buku yang berkaitan dengan kelekatan orangtua dan pembentukan karakter anak. Sumber skunder yang peneliti gunakan adalah buku-buku dan karya ilmiah lain yang relevan dengan penelitian.

\section{Teknik Pengumpulan Data}


Menurut Amirul Hadi dan Haryono, (2008:110) Pengumpulan data dalam penelitian ini diperoleh dengan melalui dokumen-dokumen. Dokumen yang penulis perlukan dalam penelitian ini adalah mengumpulkan data-data yang ada baik melalui buku-buku, ataupun yang berhubungan dengan penelitian ini, menganalisis data yang ada untuk dipilih dan disesuaikan dengan materi.

\section{Teknik Analisis Data}

Teknik pengumpulan data yang dkumpulkan dengan dokumentasi, maka dalam hal ini metode yang peneliti gunakan diantaranya menganalisis data berkenaandengan penelitian ini adalah dengan menggunakan teknik analisis isi atau content analisis

Menurut Emzir, (2011:284) Analisis isi adalah suatu analisis mendalam terhadap pesanpesan menggunakan metode ilmiah dan tidak terbatas pada jenis-jenis variable yang dapat diukur atau konteks tempat pesan-pesan disiptakan atau disajikan.

Setelah data dikumpulkan melalui dokumentasi, data tersebut diinterpretasi secara mendalam untuk mengambil pesan-pesan atau makna yang terdapat didalamnya.

\section{TEMUAN}

\section{Kelekatan dan Pembentukan Karakter}

Kedudukan keluarga sebagai salah satu ruang lingkup pembangunan karakter bangsa, mempunyai peran yang penting dalam pendidikan karakter bagi putra-putrinya. Posisi keluarga sebagai awal pembentukan kepribadian anak yang berkarakter. Anak mendapatkan kesan pertama mengenai dunia melalui perilaku dan sikap orang tua, terutama ibu terutama di awal usianya. Jika ibu berlaku baik maka kesan anak tentang dunia dan lingkungan positif dan sikap anak juga akan menjadi positif. Hal ini dapat menyebabkan anak mampu mengeksplorasi lingkungan secara optimal, akibatnya perkembangan perilaku, emosi, sosial, kognitif dan kepribadian anak akan optimal pula (Stams dkk,2002: 818).

Beberapa penelitian menunjukkan bahwa kehangatan dan afeksi yang diberikan ibu pada anak akan berpengaruh pada perkembangan anak selanjutnya (Eva, 2011:13). Kehangatan dan afeksi yang diberikan ibu selanjutnya disebut kualitas hubungan orangtua dan anak. Kualitas hubungan ini jauh lebih penting dibandingkan dengan kuantitas atau lamanya waktu yang dihabiskan ibu bersama anak. Ibu yang menghabiskan waktu lebih banyak namun dengan perilaku yang buruk tidak akan membantu anak berkembang secara optimal (Pramana dalam Eva 2011:13). Kelekatan inilah yang berdampak pada kelekatan pada masa-masa mendatang. Kelekatan dimulai pada masa fase awal di tahun pertama kehidupan. Menurut Ainsworth (dalam Belsky, 1988:70) hubungan kelekatan berkembang melalui pengalaman bayi dengan pengasuh ditahun-tahun awal kehidupannya. Intinya adalah kepekaan ibu dalam memberikan respon atas sinyal yang diberikan bayi, sesegera mungkin atau menunda, respon yang diberikan tepat atau tidak.

Bowbly (dalam Santrock, 2002:45) mengungkapkan, kelekatan adalah suatu relasi antar figur sosial tertentu dengan suatu fenomena tertentu yang dianggap mencerminkan karakteristik relasi yang unik. Kelekatan yang aman sebagai landasan yang penting bagi perkembangan selanjutnya. Allen (dalam Santrock, 2007:25) berpendapat bahwa kelekatan yang aman terhadap orangtua dapat mendorong kompetensi sosial dan kesejahteraan di masa remaja. Jika kelekatan tidak aman yang diberikan oleh orangtua akan terbentuk masalah-masalah perilaku pada remaja. Hal tersebut diperkuat oleh penjelasan George (dalam Santrock, 2007:177) menyatakan kelekatan tidak aman antara orangtua dengan remaja akan membetuk perilaku dan karakter yang negatif. 
Kelekatan adalah suatu hubungan emosional antara satu individu dengan individu lainnya yang mempunyai arti khusus, Hubungan yang dibina akan bertahan cukup lama dan memberikan rasa aman dan menumbuhkan rasa percaya diri. Hubungan ini dapat membantu anak membangun intersaksi sosial yang baik.(Bowbly dalam Engless, 2001:429). Anak yang merasa yakin terhadap penerimaan lingkungan akan mengembangkan kelekatan yang aman dengan figur lekatnya (secure attachment) dan mengembangkan rasa percaya tidak saja pada ibu juga pada lingkungan. Hal ini akan membawa pengaruh positif dalam proses perkembangannya. Oleh karena itu kelekatan ibu tidak hanya menularkan kehangat secara fisik, namun juga kognisi dan afeksi yang dirasakan bersama.

\section{DISKUSI}

Keluarga terutama orangtua hal yang pertama yang ditemui anak setelah lahir, anak akan mendapat pendidikan pertama dari orangtua, pendidikan tersebut yang akan membentuk perilaku dan karakter anak setelah dewasa, sejatinya orangtua yang dapat menentukan masa depan anak.

Para ahli menyatakan babarapa factor yang membentuk karakter anak diantaranya lingkungan anak, dimana lingkungan anak salah satunya orangtua atau keluarga, orangtua dituntut membetuk karakter anak dengan mengenalkan nilai-nilai moral dan kebiasaan yang baik kepada anak, disinilah orangtua juga dituntut untuk memberikan pola asuh yang tepat pada anak, dalam polah asuh akan dapat membetuk ikatan emosional anak dengan orangtua, dimana ikatan emosional ini disebut dengan kelekatan.

Kelekatan adalah hubungan timbal balik antara anak dan orangtua. Hubungan tersebut merupakan ikatan kasih sayang dan sikap orangtua dalam mengasuh anak, orangtua mampu merespon, dan memenuhi kebutuhan anak, hubungan ini akan membentuk suatu ikatan emosional antara anak dengan orangtua dan terjalin kedekatan anak dengan orangtua, dari hubungan tersebut tercipta rasa aman. Hubungan ini akan berlangsung dalam jangka waktu yang lama bahkan usia lanjut dan akan terbentuk pola-pola kelekatan pada anak.

Kelekatan yang positif antara anak dengan orangtua akan memberikan kesejahteraan sosial pada anak, anak akan memiliki harga diri yang tinggi, mampu mengendalikan emosi, dan kesehatan fisik sehingga anak mampu menguasai lingkungan yang baru dan mampu menghasilkan hubungan yang positif.

Kelekatan orangtua berperan penting dalam kehidupan anak, walaupun menginginkan otonomi, anak terkait dengan orangtuanya, kelekatan anak dengan orangtua merupakan sumber dukungan bagi anak dalam menghadapi proses perkembangannya.

Kelekatan orangtua yang tinggi pada anak ditunjukkan dengan kepercayaan, dapat membantu, menerima diri anak apa adanya, memberikan cinta dan kepedulian yang layak pada anak. Kualitas yang tinggi dapat membuat individu melihat dirinya layak untuk dicintai dan memandang individu dilingkungan sosialnya dapat diandalkan serta dapat berpikir positif dalam menjalani hidup.

Anak yang memiliki kelekatan yang baik dengan orangtua akan dapat memiliki rasa percaya terhadap orangtua dan menjalin komunikasi yang baik dengan orangtua, begitu pula sebaliknya orangtua akan memberikan respon yang baik disaat anak mau menjalin komunikasi dengan orangtua mereka. Tetapi jika anak tidak memiliki kelekatan yang baik dengan orangtua ditandai dengan adanya perasaan marah atau pengabaian dari orangtua pada anak sehingga kurangnya kepercayaan serta jalinan komunikasi antara anak dengan orangtua.

Senada dengan hal tersebut, maka kelekatan yang dijalin orang tua terhadap anaknya mampu meminimalisir tindakan kriminal, kekerasan, dan perilaku-perilaku negatif yangsekarang banyak terjadi di masyarakat dan di sekolah, tidak lepas dari pengasuhan orangtua. Oleh karena itu,orangtua hendaknya memahami dan mengerti tentang kebutuhan anak. Hal ini dapat dilakukan dengan cara memberikan rasa nyaman kepada anak bila dekat dengan orangtua sehingga terjalin 
percakapan yang nyaman. Kelekatan yang positif antara anak dengan orangtua akan memberikan kesejahteraan sosial pada anak, anak akan memiliki harga diri yang tinggi, mampu mengendalikan emosi, dan kesehatan fisik sehingga anak mampu menguasai lingkungan yang baru dan mampu menghasilkan hubungan yang positif.

Kesalahan orangtua dalam mendidik anak dan memberikan polah asuh akan berdampak negative pada anak. Kesalahan orangtua dalam mendidik anak akan memperngaruhi perkembangan emosi anak, anak akan kurang menujukkan kasih sayang, anak akan suka memberontak dan berbahasa kasar kepada orang-orang yang berada disekitarnya, anak akan bersifat egois. Untuk mengatasi permasalahan diiatas orangtua diharap dapat memperhatikan perkembangan anak, bekerjasama dengan pihak-pihak yang terkait yang mampu mengatasi masalah anak. Pemahaman orangtua terhadap kondisi anak sangat menentukan terbentuknya perilaku yang positif. Hal ini dapat menyebabkan anak mampu menyesuaikan diri dengan lingkungan secara optimal, perkembangan perilaku, emosi, sosial, kognitif dan kepribadian anak akan optimal pula. Selanjutnya anak akan berkembang dan memiliki karakter yang positif.

Orangtua dituntut untuk dapat memahami dan mengerti apa saja yang jadi kebutuhan anak, sehingga anak akan merasa nyaman dengan orangtua, sehingga akan terciptalah suasana yang santai serta nyaman. Orangtua dapat mendukung aktivitas yang dilakukan anak, orangtua memberikan dukurang secara emosional jika anak mengalami permasalahan dalam menjalankan aktivitasnya, orangtua juga diharapkan memberikan respon positif jika anak membutuhkan bantuan orangtua, dan memberikan kesempatan anak dalam mengungkapkan pendapat dan idenya, hal ini akan membuat anak membdapat apresiasi.

Lingkungan anak bukan hanya orangtua saja, sekolah juga merupakan tempat mendapatkan pendidikan kedua bagi anak, diharapkan pihak sekolah juga mengerti dengan kebutuhan anak, sehingga banar-benar merasa aman dan hal ini akan berpengaruh terhadap pembentukan karakter anak.

\section{DAFTAR RUJUKAN}

Amirul Hadi dan Haryono. 2008. Metodologi Penelitian. Bandung: 2008.

Armsden, G., dan Greenberg, M. T. 1987. "The Inventory of Parent and Peer Attachment: Individual differences and their relationship to psychological well-being in adolescence". Journal of Youth and Adolescence, 16 (5): 427-454.

Baron, A. R., dan Byrne, D. 2003. Psikologi Sosial. Terjemahan oleh Ratna Djuwita. Jakarta: Erlangga.

Belsky, J. (Ed) (1988). Infancy, Childhood and adollescene. Clinical Implication of Attachment. Lawrence Erlbaum Associate

Colin, V. 1996. Human Attachment. New York: Mc Graw Hill.

Coon, Dennis. (1983). Introduction to Psychology : Exploration and Aplication. West Publishing Co.

Emzir. 2011. Metodologi Penelitian Kualitatif: Analisis Data. Jakarta: Raja Wali Pers. 
Engless, R. 2001. "Parental Attachment and Adolescent's Emotional Adjusment: The associations with social skill and relational competence". Journal of Conseling Psychology, 48 (4): 428-439.

Eva Imania Eliasa. 2011. Karakter Sebagai Saripati Tumbuh Kembang Anak Usia Dini. Yogyakarta: Inti Media.

Lickona,T.(1992). Educating for Character, How Our Schools Can Teach Respect and Responsibility. New York: Bantam Book

Mc Cartney, K. \& Dearing, E., (Ed). (2002). Child Development. Mc Millan Refference USA

Megawangi, Ratna. (2003). Pendidikan Karakter untuk Membangun Masyarakat Madani. IPPK Indonesia Heritage Foundation.

Melly Latifah. (2008). Peranan Keluarga dalam Pendidikan Karakter. (Online). (http://tumbuhkembang-anak.blogspot.co.id/2008/03/pendahuluan saat-di-layartelevisi-kita.html). Diakses 15 Maret 2017.

Musfiroh,Tadkiroatun. (2008). Pengembangan Karakter Anak Melalui Pendidikan Karakter. TinjauanBerbagai Aspek Character Buiding. Yogyakarta : Penerbit Tiara Wacana

Papalia, D. E., Olds, S. W., dan Feldman, R. D. 2009. Human Development: Psikologi perkembangan. Terjemahan oleh A. K. Anwar. Jakarta: Kencana.

Rika Eka Izzaty. (2008). Peran Aktivitas Pengasuhan Pada Pengasuhan Perilaku Anak Sejak Usia Dini (Kajian Psikologis Berdasarkan Teori Sistem Ekologi). Tinjauan Berbagai Aspek Character Building. Yogyakarta: Penerbit Tiara Wacana

Santrock, J. W. 2002. Live Span Development. Terjemahan oleh Achmad Chusairi dan Juda Damanik. Jakarta: Erlangga.

Santrock, J. W. 2003. Adolescence: Perkembangan remaja. Terjemahan oleh Shinto dan Sherly Saragih. Jakarta: Erlangga.

Santrock, J. W. 2007. Remaja Jilid 2. Terjemahan oleh Benedictine Widyasinta. Jakarta: Erlangga.

Stams, J.M., Juffer, F., Ijzendoorn, M.H. (2002). Maternal Sensitivity , Infant Attachment and Temperament in Early Childhood Predict Adjustment in Middle Childhood: The Case of Adopted Children and Their Biologically Unrelated Parents . Journal of Developmental Psychology Volume 33 No 5 806-821. American Psychological Association Inc

Sutcliffe, J., (2002). Baby Bonding, Membentuk Ikatan Batin dengan Bayi. Jakarta: Taramedia \& Restu Agung.

Sutrisno Hadi. 2000. Metodologi Research. Yogyakarta: Andi 
Tia Rahmania. 2014. Sentra Tumbuh Kembang Anak, (Online), (http://www.kancilku.com, diakses 20 Januari 2015).

Upton, P. 2012. Psikologi Perkembangan. Terjemahan oleh Noermalasari Fajar Widuri. Jakarta: Erlangga. 